\title{
The Impact of Implementation of Standardized Quality Management Systems on Management of Liabilities in Group Purchasing Organizations
}

\author{
DOI: 10.12776/QIP.V23I1.1210
}

Dominik Zimon, Grzegorz Zimon

Received: 21 December 2018 Accepted: 14 February 2019 Published: 31 March 2019

\begin{abstract}
Purpose: The main purpose of the paper was to determine the impact of an implementation of the quality management system according to ISO 9001 on the improvement of processes related to the management of liabilities to suppliers.
\end{abstract}

Methodology/Approach: The research covered 38 Polish small trading enterprises operating in two group purchasing organizations. The research period concerned the years 2014-2016. The surveyed enterprises were divided into those that implemented standardized quality management systems (10 organizations) and the ones that do not use such solutions (28 organizations). Next, the analyses were made and the results obtained by enterprises associated in particular groups were compared.

Findings: The obtained results confirm that more effective management of liabilities towards suppliers can be observed in enterprises applying appropriate system procedures. This group includes long-term liabilities and the turnover ratio of short-term liabilities in days achieves lower results than results for enterprises that did not introduce standardized quality management systems.

Research Limitation/implication: Due to a small research sample, the obtained results can only be considered as an introduction to further research and deliberations.

Originality/Value of paper: The considerations discussed in this article concern a relatively rarely discussed subject matter in the literature.

Category: Research paper

Keywords: QMS; commitment management; improvement 


\section{INTRODUCTION}

In the subject literature it is emphasized that the optimal level for the debt ratio in enterprises should be at the level of 0.57 to 0.67 (Gabrusewicz, 2017; Nowak, 2017). Therefore, it is recommended to have an advantage of an equity over outside funds. From the point of view of the structure of liabilities, it is important that long-term liabilities and obligations to suppliers were included in it. It should be remembered that the trade credit granted by suppliers is the cheapest source of financing for the unit. Virtually without interest, it is worth supporting this form of financing individuals. On the other hand, too much support with foreign capital may result in the loss of financial liquidity. In the case of increasing liabilities, it is easy to make mistakes that may result in the loss of an additional discount for early payment of obligations to the supplier. In the case of group purchasing organizations such occasions often appear and should be used. Purchasing groups are based on the use of economies of scale, which allows the negotiation of the representative of the group with the producer to lower the price and negotiate an additional discount for the earlier payment of obligations. (Zimon, 2018a) This action leads to a reduction of operational costs. In general, the benefits that companies gain as a result of activities in the purchasing group include the reduction of direct and indirect costs of production, prices of purchased goods and an extended trade credit, as well as shortened delivery time. (Tella and Virolainen, 2005; Nollet and Bealulieu, 2005; Burns and Lee, 2008). Many authors also point out that acting together, creating shopping consortia allows reducing the costs of supplies (Nollet and Beaulieu, 2003; Bakker, Walker and Harland, 2006; Schotanus and Telgen, 2007). It can be concluded that the creation of trade policy in the area of purchasing slowly changes its function from tactical, short-term management to management of a strategic enterprise. (Johnsen, 2018). Especially in purchasing groups where managers often face a dilemma whether to use additional discounts for an early payment or to lengthen the repayment date. Very often it is a late decision, which may lead to errors in the department that makes payments.

Mistakes in the area of managing liabilities to suppliers happen and often lead to penal interest charges. Most often these are small amounts, but it is worth introducing a system that would improve the management process. These mistakes can be divided into two types: these that appear in the department of administration and in departments related to operating activities, e.g. on construction sites or warehouses, or these that appear in administration, and which may result from missing payment dates. The second group of mistakes occurs most often in small service enterprises where the material, the goods go to a given construction, an invoice is collected by the employee and the document never reaches the accounting. Lack of procedures often causes that the goods are picked up by employees who are not authorized for such activities. Quantitative and qualitative errors in the receipt of the delivery appear, the document is forfeited and then an interest note appears in the accounting and the search for the person responsible for the situation begins. According to the authors of this 
publication, it is recommended to implement standardized quality management systems which put a lot of emphasis on developing an effective management system and developing effective forms of cooperation with suppliers. The implementation of the requirements of standardized quality management systems also leads to the organization of basic processes and significant minimization of signaled errors and mistakes (Zizka, Budaj and Madzík, 2016; Levine and Toffel, 2010). Enterprises are obliged to develop well-thought-out procedures, implement improvement actions and carry out regular system reviews (Fonseca and Domingues, 2018; Zgodavova, Kisela and Sutoova, 2016). The review of the quality management system should cover all activities carried out by the company and the effects of these activities (Kafel and Simon, 2017). These are both the activities described in the system procedures (audits, quality records, corrective and preventive actions, etc.) and operational procedures (production, logistics, sales, finances or marketing, etc.). In addition, the review should take into account all levels of management, starting from the simplest workstations on the board ending. The final result of the reviews should be a program of actions improving all areas of the organization's operation both in the short and long time horizon (Dellana and Kros, 2018). With this in mind, the following research hypothesis was adopted: it is assumed that an implementation of standardized quality management systems may affect the effectiveness and efficiency of commitment management strategies in organizations that co-create purchasing groups.

\section{LIABILITY MANAGEMENT STRATEGIES IN GROUP PURCHASING ORGANIZATIONS}

Managers decide what strategy for managing the sources of financing they will use and they have to choose between aggressive, moderate and conservative strategies.

The classic strategies should be modified because it is difficult on the basis of the presented guidelines to adapt the company to a given strategy. The new guidelines for commitment management strategies are as follows (Zimon, 2018b):

- Safe (conservative) strategy, characterized by high financial liquidity. In the structure of financing sources, the predominance of equity over foreign capital is clearly visible. Long-term bank loans must exist in the structure of liabilities and provisions for liabilities.

- Risky (aggressive) strategy whose characteristic feature is a low level of financial liquidity. The structure of financing sources is dominated by liabilities over equity. There are no long-term bank loans in the structure of liabilities and provisions for liabilities. This type of strategy should be characterized by a predominance of liabilities towards suppliers over 
receivables from recipients. In the structure of short-term liabilities, liabilities to suppliers constitute a high share.

- Moderate (indirect) strategy based largely on the conservative strategy. The structure of financing sources is dominated by equity over foreign capital. Long-term bank loans appear in the structure of liabilities and provisions for liabilities. This type of strategy is characterized by a clear advantage of receivables from customers over liabilities to suppliers. Often this ratio achieves the results around 2 or above 2. Managers, in contrast to the conservative strategy, do not quickly collect debts. They also use a long period to pay off their debts. The receivables turnover ratio in days is at a similar level to the liabilities turnover ratio. Short-term liabilities in the structure of short-term liabilities are bank loans. In the article, enterprises were evaluated in terms of modified and presented new commitment management strategies.

In group purchasing organizations the central unit of the group negotiates prices with the producer, payment deadline and possible rebate for earlier payment. The cash flow is as follows.

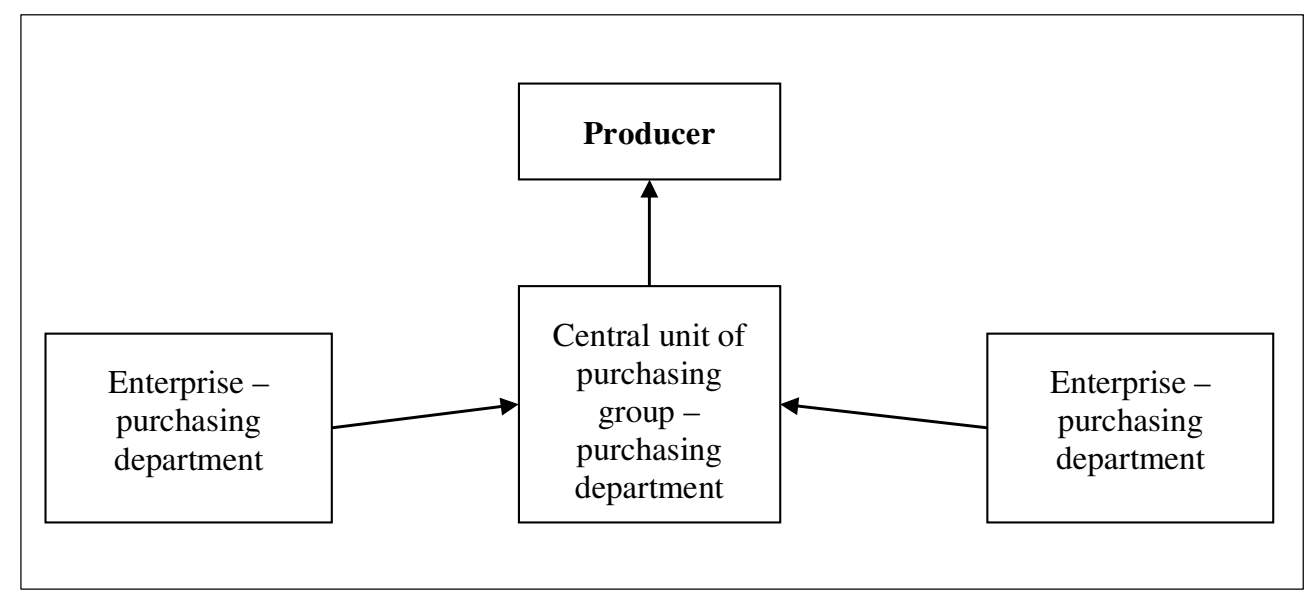

Figure 1 - Cash Flow in the Group Purchasing Organization

It is important to respect the deadlines as delays may result in the loss of benefits for individual participants of the purchasing group. It is, therefore, worth introducing standardized quality management systems that will allow developing appropriate procedures for managing liabilities. Personnel involved in the settlement of obligations needs to have a clearly separated range of duties. The managers of the given units have to in a timely manner present the value of future liabilities to be settled, broken down into interest and not interest. The budget commitments that needs to be paid must be clearly identified. Persons responsible for the process of settling liabilities must have at all times 
information about available funds and on current liabilities. Therefore, the flow of information is very important, as there are no payment bottlenecks in the enterprise because a situation may arise that an element that cannot be bought is needed to complete the investment because the producer blocked the sale. At that time, the managers made a mistake and settled other liabilities instead of the key one. Such situations should be avoided. Therefore, the persons deciding on the payment queue should receive a lot of information on finance as well as investments, production and works that are carried out in the enterprise.

As already indicated in the introduction, quality management systems can significantly contribute to organizing processes in the organization, minimizing errors and introducing solutions that effectively prevent their formation (Bugdol and Jedynak, 2015). These systems are based on seven basic principles and one of them is an improvement (Domingues, Sampaio and Arezes, 2016). The term improvement should not be understood only as counteracting errors, but also as any actions leading to a gradual improvement of the efficiency of processes in the organization through the use of new technologies, techniques, methods, materials or better organization of work (Zimon, 2017). Improving the organization should be based on the following rules:

- improvement is a sequence of activities focused on solving and correcting detected and predicted problems,

- an improvement process should be monitored in order to improve its effectiveness,

- each organization, due to its specificity, should choose the most optimal pace of improvement activities,

- the guiding principle of improvement should be broadly understood customer good.

An implementation of the above-mentioned rules will allow a clear division of duties and responsibilities and a quick diagnosis of possible mistakes. Employees will therefore get tools that will allow them to make the right decisions and reduce the risk of mistakes (Psomas, Kafetzopoulos and Fotopoulos, 2012).

\section{TEST METHOD}

The purpose of the analysis was to determine the impact of the implementation of the requirements of standardized quality management systems on the improvement of processes related to the management of obligations to suppliers. The explanation of the generally discussed research problem prompted the author to formulate a research question whether an introduction of quality management systems can be considered as a tool that positively influences the process of managing liabilities towards suppliers? The main reasons for the interest in this research subject include a small number of studies on the impact of quality management systems on the process of managing liabilities. 
The research covered 38 Polish small trading enterprises operating in two purchasing groups. The enterprises belong to branch purchasing groups operating in the construction industry. Enterprises operating in purchasing groups generate turnover in the range from PLN 10 million (USD 2 million) to PLN 120 million. (USD 30 million). The research period concerned the years 2014-2016. The surveyed enterprises were divided into those which implemented quality management systems according to ISO 9001 standard (10 organizations) and those that do not use such solutions (28 organizations). The analyzes were made and the results obtained by enterprises associated in particular groups were compared. The analysis of financial ratios and statistical methods were used as the basic research tools. The research period covered the years 2014-2017.

\section{AN ANALYSIS OF THE IMPACT OF QUALITY MANAGEMENT SYSTEMS ON THE LEVEL OF LIABILITIES}

The first stage of the research process was to conduct a preliminary financial analysis in the area of the structure of liabilities. The results for enterprises that do not apply quality management systems are presented in the Tab. 1 .

Table 1 - Ratios of the Structure of Liabilities in Enterprises that Do Not Introduce Quality Management Systems in 2016 (Author's Own Study)

\begin{tabular}{|c|c|c|}
\hline Enterprise & $\begin{array}{c}\text { Share of debts } \\
\text { in total liabilities (\%) }\end{array}$ & $\begin{array}{c}\text { Share of long-term liabilities } \\
\text { to total liabilities (\%) }\end{array}$ \\
\hline 1 & 30 & 0 \\
\hline 2 & 34 & 0 \\
\hline 3 & 80 & 4 \\
\hline 4 & 71 & 0 \\
\hline 5 & 24 & 58 \\
\hline 6 & 78 & 0 \\
\hline 7 & 23 & 0 \\
\hline 8 & 73 & 37 \\
\hline 9 & 49 & 0 \\
\hline 10 & 54 & 0 \\
\hline 11 & 62 & 0 \\
\hline 12 & 53 & 0 \\
\hline 13 & 54 & 0 \\
\hline 14 & 5 & \\
\hline 15 & 17 & 0 \\
\hline & & \\
\hline
\end{tabular}




\begin{tabular}{|c|c|c|}
\hline Enterprise & $\begin{array}{c}\text { Share of debts } \\
\text { in total liabilities } \mathbf{( \% )}\end{array}$ & $\begin{array}{c}\text { Share of long-term liabilities } \\
\text { to total liabilities (\%) }\end{array}$ \\
\hline 16 & 26 & 0 \\
\hline 17 & 35 & 0 \\
\hline 18 & 55 & 0 \\
\hline 19 & 49 & 0 \\
\hline 20 & 64 & 0 \\
\hline 21 & 12 & 7 \\
\hline 22 & 62 & 0 \\
\hline 23 & 24 & 10 \\
\hline 24 & 81 & 0 \\
\hline 25 & 34 & 0 \\
\hline 26 & 9 & 0 \\
\hline 27 & 70 & 0 \\
\hline 28 & 63 & \\
\hline
\end{tabular}

In the analyzed group, model results in the range of 0.57-0.67 for the debt ratio were recorded in 8 out of 28 enterprises. In 14 the results are below this range in turn in 6 above. It can be seen that the analyzed enterprises maintain the level of liabilities in the theoretically safe range, do not exceed the level of 0.67. One can only accuse these enterprises that they should use foreign capital to finance their property to a greater extent. The share of long-term liabilities in liabilities should be assessed negatively, it appears in only 7 enterprises. Long-term liabilities in the analyzed enterprises are long-term loans. In general, they are assessed as a safe source of financing for enterprises. Tab. 2 presents the indicators of the structure of liabilities in enterprises applying quality management systems.

Table 2 - Ratios of the Structure of Liabilities in Enterprises that Introduce Quality Management Systems in 2016 (Author's Own Study)

\begin{tabular}{|c|c|c|}
\hline Enterprise & $\begin{array}{c}\text { Share of debts } \\
\text { in total liabilities (\%) }\end{array}$ & $\begin{array}{c}\text { Share of long-term liabilities } \\
\text { to total liabilities (\%) }\end{array}$ \\
\hline 1 & 36 & 0 \\
\hline 2 & 84 & 0 \\
\hline 3 & 80 & 5 \\
\hline 4 & 57 & 0 \\
\hline 5 & 14 & 4 \\
\hline 6 & 53 & 26 \\
\hline
\end{tabular}




\begin{tabular}{|c|c|c|}
\hline Enterprise & $\begin{array}{c}\text { Share of debts } \\
\text { in total liabilities (\%) }\end{array}$ & $\begin{array}{c}\text { Share of long-term liabilities } \\
\text { to total liabilities (\%) }\end{array}$ \\
\hline 7 & 36 & 0 \\
\hline 8 & 58 & 20 \\
\hline 9 & 15 & 10 \\
\hline 10 & 65 & 1 \\
\hline
\end{tabular}

When assessing companies using quality management systems, up to 0.67 obtained 8 out of 10 enterprises. It is a safe policy of managing liabilities that does not have a negative impact on financial liquidity, but it is worth increasing the engagement of liabilities in the structure to make the model results more than 4 companies. The appearance of long-term liabilities should be positively assessed, occurring in 6 enterprises.

Tab. 3 and Tab. 4 present detailed results of the turnover of short-term liabilities in days in 2014-2016. Tab. 3 presents the results for enterprises that do not apply quality management systems.

Table 3 - Liabilities Rotation Rates in Days in the Analyzed Enterprises that Did Not Apply Quality Management Systems in 2014-2016 (Author's Own Study based on the Financial Statements of Enterprises)

\begin{tabular}{|c|c|c|c|}
\hline Enterprise & $\mathbf{2 0 1 6}$ & $\mathbf{2 0 1 5}$ & $\mathbf{2 0 1 4}$ \\
\hline 1 & 79 & 63 & 66 \\
\hline 2 & 22 & 17 & 109 \\
\hline 3 & 96 & 101 & 46 \\
\hline 4 & 38 & 40 & 35 \\
\hline 5 & 43 & 45 & 113 \\
\hline 6 & 127 & 114 & 156 \\
\hline 7 & 22 & 27 & 85 \\
\hline 8 & 72 & 60 & 56 \\
\hline 9 & 71 & 67 & 22 \\
\hline 10 & 37 & 25 & 14 \\
\hline 11 & 20 & 10 & 64 \\
\hline 12 & 60 & 57 & 20 \\
\hline 13 & 21 & 27 & 79 \\
\hline 14 & 63 & 59 & 20 \\
\hline 15 & 31 & 26 & \\
\hline
\end{tabular}




\begin{tabular}{|c|c|c|c|}
\hline Enterprise & $\mathbf{2 0 1 6}$ & $\mathbf{2 0 1 5}$ & $\mathbf{2 0 1 4}$ \\
\hline 16 & 41 & 36 & 26 \\
\hline 17 & 116 & 103 & 11 \\
\hline 18 & 99 & 98 & 103 \\
\hline 19 & 48 & 69 & 62 \\
\hline 20 & 16 & 23 & 33 \\
\hline 21 & 113 & 128 & 97 \\
\hline 22 & 102 & 104 & 96 \\
\hline 23 & 122 & 88 & 82 \\
\hline 24 & 89 & 81 & 94 \\
\hline 25 & 96 & 95 & 93 \\
\hline 26 & 94 & 78 & 18 \\
\hline 27 & 32 & 32 & 108 \\
\hline 28 & 107 & 116 & 83 \\
\hline
\end{tabular}

Tab. 4 presents the detailed results of receivables turnover rates in days for units using quality management systems.

Table 4 - Liabilities Rotation Rates in Days in the Analyzed Enterprises Applying Quality Management Systems in the Years 2014-2016 (Author's Own Study Based on the Financial Statements of Enterprises)

\begin{tabular}{|c|c|c|c|}
\hline Enterprise & $\mathbf{2 0 1 4}$ & $\mathbf{2 0 1 5}$ & $\mathbf{2 0 1 6}$ \\
\hline 1 & 48 & 33 & 36 \\
\hline 2 & 78 & 45 & 43 \\
\hline 3 & 62 & 47 & 55 \\
\hline 4 & 36 & 32 & 39 \\
\hline 5 & 49 & 64 & 57 \\
\hline 6 & 83 & 83 & 67 \\
\hline 7 & 81 & 51 & 63 \\
\hline 8 & 64 & 40 & 51 \\
\hline 9 & 37 & 18 & 33 \\
\hline 10 & 41 & 43 & 47 \\
\hline
\end{tabular}


Tab. 5 and Tab. 6 present the results of statistical surveys for the analyzed enterprises. Tab. 5 presents average ratios for the analyzed enterprises (the test probability value is marked as mark ' $p$ ').

Table 5 - Average Results of Liabilities Turnover in the Days of the Analyzed Enterprises (Author's Own Study)

\begin{tabular}{|c|c|c|c|c|c|c|c|c|c|c|c|}
\hline \multirow{2}{*}{$\begin{array}{c}\text { Liabilities } \\
\text { turnover } \\
\text { ratio in } \\
\text { days }\end{array}$} & \multicolumn{9}{|c|}{ Group } & \multirow{2}{*}{$\boldsymbol{*} \begin{array}{c}\text { Enterprises that do not use quality } \\
\text { management systems }(\boldsymbol{N}=\mathbf{2 8})\end{array}$} & \multicolumn{4}{c|}{$\begin{array}{c}\text { Enterprises that use quality } \\
\text { management systems B }(\boldsymbol{N}=10)\end{array}$} & \\
\cline { 2 - 13 } & $\bar{x}$ & $\mathrm{Me}$ & $s$ & $\min$ & $\max$ & $\bar{x}$ & $\mathrm{Me}$ & $s$ & $\min$ & $\max$ & \\
\hline 2014 & 64.7 & 65.0 & 38.5 & 11 & 156 & 49.1 & 49.0 & 11.5 & 33 & 67 & 0.3505 \\
\hline 2015 & 63.9 & 61.5 & 34.6 & 10 & 128 & 45.5 & 43.5 & 18.0 & 18 & 83 & 0.2304 \\
\hline 2016 & 67.0 & 67.0 & 36.0 & 16 & 127 & 57.5 & 55.5 & 18.4 & 36 & 83 & 0.5901 \\
\hline
\end{tabular}

The conducted analysis showed the existence of differences for the average and median in the analyzed enterprises. Quite large differences in the level of averages for the ratio of liabilities turnover in days and financial liquidity are not statistically significant as they are relatively small in relation to the range of variability of this ratio in each group (standard deviations are large in relation to the difference between groups). However, it should be noted that the results for a group of companies using standardized quality management systems are lower. When analyzing the detailed results, one did not observe very high results reaching results above 90 days. In enterprises operating without a quality management system, they often achieve results within 90 days and over 100 days.

The level and strategy of managing short-term liabilities have a decisive influence on the results of the financial liquidity ratio. The table below presents average results for the current liquidity ratio in 2014-2016 in the analyzed enterprises.

Table 6 - Average Financial Liquidity Results in the Analyzed Enterprises (Author's Own Study)

\begin{tabular}{|c|c|c|c|c|c|c|c|c|c|c|c|}
\hline \multirow{2}{*}{$\begin{array}{c}\text { Financial } \\
\text { Liquidity }\end{array}$} & \multicolumn{9}{|c|}{ Group } & \multirow{2}{*}{$\boldsymbol{p}$} \\
\cline { 2 - 12 } & \multicolumn{1}{|c|}{$\begin{array}{c}\text { Enterprises that do not use quality } \\
\text { management systems (N = 28) }\end{array}$} & \multicolumn{4}{|c|}{$\begin{array}{c}\text { Enterprises that use quality } \\
\text { management systems B (N = 10) }\end{array}$} & \\
\cline { 2 - 12 } & $\bar{x}$ & $\mathrm{Me}$ & $s$ & $\min$ & $\max$ & $\bar{x}$ & $\mathrm{Me}$ & $s$ & $\min$ & $\max$ & \\
\hline 2014 & 3.62 & 1.85 & 3.21 & 0.13 & 12.0 & 2.78 & 2.80 & 0.88 & 1.30 & 4.1 & 0.5241 \\
\hline 2015 & 3.65 & 1.90 & 3.29 & 1,20 & 15.0 & 3.10 & 3.30 & 0.87 & 1.20 & 4.2 & 0.5029 \\
\hline 2016 & 3.55 & 1.90 & 2.89 & 1.20 & 11.0 & 3.02 & 2.40 & 1.65 & 1.20 & 7.0 & 0.5901 \\
\hline
\end{tabular}


Fast turnover of short-term liabilities allows reducing the level of short-term liabilities. The median result for enterprises using quality management systems of the financial liquidity ratio indicates overliquidity as compared to enterprises not using quality management systems. Then, the correlation between the turnover ratio of short-term liabilities and the financial liquidity ratio was examined. The analysis was carried out for data from 2016, determining the Spearman rank correlation (R) coefficient matrix between pairs of ratios. The research shows that financial liquidity is very strongly connected with the level of short-term liabilities $(R=-0.94)$, the negative sign of the coefficient results from the negative significance of the level of liabilities. In view of such a strong correlation, it can be concluded that the ranking of companies' financial standing in relation to liquidity is almost identical to the liabilities or the Quick Ratio these measures can be used interchangeably with liquidity.

\section{CONCLUSIONS}

The conducted research is an introduction to further research related to the subject of the impact of quality management systems on the level of financial liquidity. The presented analysis showed that in the surveyed enterprises lower results of the short-term liabilities turnover ratio were recorded in enterprises applying quality management systems. In the group of these enterprises, longterm liabilities in the structure of liabilities appear more often. In the group applying quality management systems, the share of liabilities in asset financing more often achieves results below the model size range of 0.57-0.67. These results indicate that higher financial liquidity should be obtained by enterprises applying quality management systems, this is confirmed by statistical surveys and more precisely by the results of the median. The presented results confirm that more effective management of liabilities towards suppliers can be observed in enterprises applying appropriate system procedures. This group includes longterm liabilities and the ratio of short-term liabilities turnover in days achieves lower results than results for enterprises that did not introduce quality management systems. In addition, this efficiency translates into high financial liquidity, which is confirmed by a strong correlation between the ratio of shortterm liabilities to financial liquidity $(\mathrm{R}=-0.94)$. And financial liquidity is currently one of the basic measures informing the environment of a strong competitive position of the company. Summing up, it can be stated that an effective and effective quality management system can effectively support the analyzed processes and be a starting point for consolidating positive relationships with suppliers.

Based on the above conclusions, it can be sum up that the research hypothesis raised by the authors has been confirmed. 


\section{REFERENCES}

Bakker, E., Walker. H. and Harland C., 2006. Organising for collaborative procurement: an initial conceptual framework. Advancing Public-Procurement: Practices, Innovation and Knowledgesharing, PrAcdemics Press, pp.14-44.

Bugdol, M. and Jedynak, P. eds., 2015. Integrated management systems. Cham, Switzerland: Springer.

Burns, L.R. and Lee, J.A., 2008. Hospital purchasing alliances: Utilization, services, and performance. Health Care Management Review, 33(3), pp.7-17. https://doi.org/10.1097/01.HMR.0000324906.04025.33.

Dellana, S. and Kros, J., 2018. ISO 9001 and supply chain quality in the USA. International Journal of Productivity and Performance Management, 67(2), pp.297-317. https://doi.org/10.1108/IJPPM-05-2015-0080.

Domingues, P., Sampaio, P. and Arezes, P.M., 2016. Integrated management systems assessment: a maturity model proposal. Journal of Cleaner Production, 124, pp.164-174. https://doi.org/10.1016/j.jclepro.2016.02.103.

Fonseca, L.M. and Domingues, J.P., 2018. Empirical research of the ISO 9001: 2015 transition process in Portugal: Motivations, benefits, and success factors. Quality Innovation Prosperity, 22(2), pp.16-46. http://dx.doi.org/10.12776/qip.v22i2.1099.

Gabrusewicz, W., 2016. Analiza finansowa przedsiębiorstwa. Teoria $i$ zastosowanie. Warszawa: Polskie Wydawnictwo Ekonomiczne.

Johnsen, T.E., 2018. Purchasing and supply management in an industrial marketing perspective. Industrial Marketing Management, 69, pp.91-97. https://doi.org/10.1016/j.indmarman.2018.01.017.

Kafel, P. and Simon, A., 2017. The Reasons for Decertification of ISO 9001: Financial Aspects. Quality Innovation Prosperity, 21(3), pp.173-184. http://dx.doi.org/10.12776/qip.v21i3.1024.

Levine, D.I. and Toffel, M.W., 2010. Quality management and job quality: How the ISO 9001 standard for quality management systems affects employees and employers. Management Science, 56(6), pp.978-996. http://dx.doi.org/10.1287/mnsc.1100.1159.

Nollet J. and Beaulieu, M., 2005. Should an organization join a purchasing group?. Supply Chain Management: An International Journal, 10(1), pp.11-17. https://doi.org/10.1108/13598540510578333.

Nollet, J. and Beaulieu, M., 2003. The development of group purchasing: an empirical study in the healthcare sector. Journal of Purchasing and Supply Management, 9, pp.3-10. https://doi.org/10.1016/S0969-7012(02)00034-5.

Nowak, E., 2017. Analiza sprawozdań finansowych. Warszawa: Polskie Wydawnictwo Ekonomiczne. 
Psomas, E.L., Kafetzopoulos, D.P. and Fotopoulos, C.V., 2012. Developing and validating a measurement instrument of ISO 9001 effectiveness in food manufacturing SMEs. Journal of Manufacturing Technology Management, 24(1), pp.52-77. https://doi.org/10.1108/17410381311287481.

Schotanus, F. and Telgen, J., 2007. Developing a typology of organisational forms of cooperative purchasing. Journal of Purchasing \& SupplyManagement, 13, pp.53-68. https://doi.org/10.1016/j.pursup.2007.03.002.

Tella, E. and Virolainen, V.M., 2005. Motives behind purchasing consortia. International Journal of Production Economics, 93, pp.161-168. https://doi.org/10.1016/j.ijpe.2004.06.014.

Zgodavova, K., Kisela, M. and Sutoova, A., 2016. Intelligent approaches for an organisation's management system change. The TQM Journal, 28(5), pp.760773. https://doi.org/10.1108/TQM-10-2015-0130.

Zimon, D., 2017. Quality Management Systems' impact on the functioning of distribution channels in the FMCG market. Quality Access to Success, 18(156), pp.52-54.

Zimon, G., 2018a. Influence of group purchasing organizations on financial situation of Polish SMEs. Oeconomia Copernicana, 9(1), pp.87-104. https://doi.org/10.24136/oc.2018.005.

Zimon, G., 2018b. Strategie zarządzania zobowiązaniami w grupach zakupowych. Prace Naukowe Uniwersytetu Ekonomicznego we Wrocławiu, 513, pp.468-477.

Zizka, M., Budaj, P. and Madzík, P., 2016. The adequacy of an organisation's measurement system in quality management. Quality Access to Success, 17(155), pp.60-62. 


\section{ABOUT AUTHORS}

Dr. Dominik Zimon - works as an professor assistant in Department of Management Systems and Logistics at Rzeszów University of Technology. His scientific and research interests include first of all modern concepts of quality management and logistics management. He is author of over one hundred publications in the field of quality management and logistics. E-mail: zdomin@prz.edu.pl. Author's ORCID: https://orcid.org/0000-0002-3097-5445.

Grzegorz Zimon - Employed as an assistant professor at the Rzeszów University of Technology in the Department of Finance, Banking and Accounting. Author of over 100 papers. His main research interests concern the management of working capital, costs and logistics. In recent years he has conducted research on the financial management of enterprises operating within the purchasing organizations. E-mail: gzimon@prz.edu.pl. Author's ORCID: https://orcid.org/0000-0002-2040-4438.

(C) 2019 by the authors. Submitted for possible open access publication under the terms and conditions of the Creative Commons Attribution (CC-BY) license (http://creativecommons.org/licenses/by/4.0/). 